\title{
Are serum molecular markers more effective than the invasive methods used in the diagnosis of breast cancers?
}

\section{Meme kanserlerinin tanısında, serum moleküler belirteçleri invazif yöntemlere göre daha mı etkilidirler?}

https://doi.org/10.1515/tjb-2021-0001

Received January 3, 2021; accepted May 15, 2021;

published online June 2, 2021

\section{Abstract}

Objectives: The most effective method currently used in breast cancer diagnosis is fine-needle aspiration biopsy. However, if the superiority of serum molecular markers to invasive diagnostic methods can be proven, it will have a great impact on the diagnostic approach and screening programs for breast cancer. The aim of this study is to demonstrate the efficacy of the serum molecular markers in the diagnosis of breast cancer with respect to invasive methods. Materials and Methods: In this study, the literature on serum molecular markers and tissue molecular markers obtained using fine needle aspiration biopsy were collected. The absolute sensitivity rates obtained for serum molecular markers and for invasive needle biopsy methods were compared by systematic biostatistical analysis.

Results: In the diagnosis of breast cancer, the absolute sensitivity rates of serum molecular markers $(90.6 \%)$ were found to be significantly higher than the absolute sensitivity rates of invasive methods $(80.7 \%)$ ( $\mathrm{p}<0.001)$.

Conclusions: These results indicate that, serum molecular markers, can be used safely in breast cancer screening,

*Corresponding author: Nazmi Özer, PhD, Department of Biochemistry, Faculty of Pharmacy, Girne American University, 99428, Kyrenia, Cyprus, E-mail: nazmiozer@gau.edu.tr. https://orcid.org/ 0000-0002-2630-741X

Hasan Zafer Acar, Department of General Surgery, Faculty of Medicine, Girne American University, Kyrenia, Cyprus. https://orcid.org/00000001-6435-8720 definitive diagnosis and follow-up. Therefore, in the near future, serum molecular markers are likely to take a higher priority in breast cancer diagnosis and screening.

Keywords: breast cancer; diagnosis; molecular markers.

\section{öz}

Amaç: Günümüzde meme kanserinin tanısında kullanılan en etkili yöntem ince iğne aspirasyon biyopsisidir. Eğer, noninvaziv bir yöntem olarak, serum moleküler belirteçlerinin invaziv tanı yöntemlerine üstünlüğü kanıtlanabilirse, meme kanserinin tanı, tarama ve takibi programları üzerinde büyük etkisi olacaktır. Bu çalışmanın amac1, meme kanseri tanısında serum moleküler belirteçlerinin, invaziv yöntemlere göre daha etkin olduğunu göstermeye çalışmaktır.

Gereç ve Yöntem: Bu çalışmada, meme kanseri tanısında kullanılan serum moleküler belirteçleri ve ince iğne biyopsisi ile elde edilen moleküler belirteçleri içeren yayınlar derlenmiştir. Serum moleküler belirteçler yöntemi ve invaziv ince iğne biyopsisi yöntemi ile elde edilen mutlak duyarlılık oranları sistematik biyoistatistiksel analiz yapılarak değerlendirilmiştir.

Bulgular: Meme kanseri tanısinda serum moleküler belirteçlerinin kullanıldığı çalışmalarda elde edilen mutlak duyarlılık oranları (\%90.6), invaziv yöntemlerin kullanıldığı çalışmalarda elde edilenlere göre (\%80.7) istatistiksel olarak anlamlı derecede yüksek bulunmuştur ( $\mathrm{p}<0.001)$.

Sonuç: Elde edilen sonuçlar, serumda bulunan moleküler belirteçlerin, meme kanseri taraması, kesin tanı ve takibinde güvenle kullanılabilecek noninvaziv bir yöntem olduğunu göstermektedir. Bu nedenle yakın gelecekte meme kanseri için tanısal yaklaşım ve tarama programlarında serum 
moleküler belirteçlerinin daha yüksek bir öncelik alması muhtemeldir.

Anahtar kelimeler: meme kanseri; moleküler belirteçler; tani.

\section{Introduction}

Nowadays, in the diagnosis of breast cancer (BC), various non-invasive methods [1] (such as mammography, ultrasonography, doppler ultrasonography, elastography, magnetic resonance) and invasive methods [2] (serum molecular markers (MMs) and tissue molecular markers [3] obtained using fine needle aspiration biopsy (FNB) [4], core needle biopsy (CNB) [5], true-cut needle biopsy [6]) are used. Unfortunately, the noninvasive methods are ineffective in the diagnosis of small nodules. MMs have a key feature not only in the diagnosis but also in the prognosis and treatment of $\mathrm{BC}$. When the molecular structure of a cancer cell is revealed by the analysis of MMs in BC cases, the way for personalized treatment could be provided.

In $\mathrm{BC}$, there are two basic methods related to molecular diagnosis: MMs studied in tissues (or cell samples) and MMs studied in serum. In a study conducted by Radojicic et al., it was found that in triple negative breast cancers (TNBC), miR-21, miR-210 and miR-222 were significantly overexpressed, whereas miR-10b, miR-145, mir-205 and miR-122a significantly underexpressed [7]. Tang et al. [8] has shown that colorectal cancer associated transcript 1 (CCAT1) is a novel long noncoding RNA (LncRNA) plays an important role in the diagnosis and treatment of BC. Stergio et al. [9] demonstrated that mucin 1, a cell surface associated antigen (MUC1) is a much more important biomarker (BM) than the other known biomarkers such as estrogen receptor (ER), progesterone receptor (PR) and human epidermal growth factor receptor 2 (HER2) in BC. In a study carried out by Menekşe et al. [10], anti MUC1 IgG levels in nipple aspirate fluid, in different BC subtypes, were investigated and were found significantly higher in TNBC, ER negative tumors, HER2 neu positive tumors and could be used to predict aggressiveness of BC.

In addition, in $\mathrm{BC}$, vascular endothelial growth factorC (VEGF-C) and Twist (T) [11], dual specific phosphatase 4 mRNA expression [12], TC or BC allele formation [13], Schlafen Family Member 11 (SLFN11) mRNA expression [14], phosphoinositide 3-kinase catalytic subunit (PIK3CA) expression [15], Phosphatidylinositol binding clathrin assembly protein (PICALM) gene interacting mitotic regulator (PIMREG) [16] have been reported to be highly effective as prognostic MMs.
Apart from these, in studies related to molecular treatment of BC: miR-125a-5p and miR-181a-5p [17]; indole2-carboxamide derivative LG25 have anti TNBC potential, serine-threonine kinases Aurora A (AURKA), and p21-activated kinase 1 (PAK1) [18, 19]; miR-381 in [20] were reported in literature that they are very effective molecules in tumor suppression.

Discovery of new MMs related to the diagnosis of BC will have high potential in the effective diagnosis and treatment of BC. Therefore, in this study, it was aimed to investigate the effectiveness of serum MMs with respect to invasive $\mathrm{FNB} / \mathrm{CNB}$ methods in the diagnosis of $\mathrm{BC}$.

\section{Materials and methods}

\section{Design of the study, inclusion and exclusion criteria}

In this study, the recently published articles in literature about the MMs used in the diagnosis of $\mathrm{BC}$ were systematically reviewed. The articles reporting the values of MMs in serum and the values obtained by FNB/CNB methods in tissues were compared. The reason for including only $\mathrm{FNB} / \mathrm{CNB}$ as invasive methods to this study is that, they are still the most effective methods used in $\mathrm{BC}$ diagnosis. Since it has the highest potential as a noninvasive definitive diagnostic method, serum MMs (although studies in serum is an invasive process, it is assumed as noninvasive by researchers) were also included. Studies performed with MMs in tissues for the diagnosis of BC were not included in this study because it is also an invasive method. In order to reveal the effects of MMs in serum, the data obtained from studies conducted with serum MMs and the data obtained from studies with FNB/CNB were compared. The number of the studies performed with MMs in serum is very limited. Therefore, all studies that are found in literature were included. In this study, only articles reporting histopathologically definitive diagnosis (gold standard), were included; in which, either noninvasive MMs and invasive FNB/CNB methods were used for the diagnosis of $\mathrm{BC}$. When comparing diagnostic methods, absolute sensitivity (AS) rate (the ratio of cases diagnosed with $\mathrm{BC}$ by serum MMs or invasive methods, to the cases diagnosed with $\mathrm{BC}$ histopathologically) was taken as basis.

The $\mathrm{BC}$ cases in which the articles investigating the levels of MMs in serum were included; in a study by Heneghan et al. [21], miR-195 levels in serum in $83 \mathrm{BC}$ and 44 control cases; in a study by Han et al. [22] combined miR-21, miR-155 and miR-365 levels in $99 \mathrm{BC}$ and 21 control subjects; in a study by Shihomura et al. [23], in the serum of $1280 \mathrm{BC}$ and 2,836 non-cancer control cases, miR-1246, miR-1307-3p, miR-4634, miR-68615p, miR-6875-5p levels; in a study by Marwa et al. [24], histidine rich glycoprotein RNA levels in $60 \mathrm{BC}$ and 30 control group cases were investigated.

Articles investigating absolute sensitivity rates using invasive FNB and CNB methods in the diagnosis of $\mathrm{BC}$ that are included in this study; FNB findings reported by Kazi et al. [25] in 698 BC patients; in a study by Ohashi et al. [26], FNB findings in $238 \mathrm{BC}$ cases, CNB findings in $133 \mathrm{BC}$ cases; in a study conducted by Kurita et al. [27], FNB findings in $182 \mathrm{BC}$ cases, CNB findings in $56 \mathrm{BC}$ cases, and combined FNB/CNB findings in $43 \mathrm{BC}$ cases. In the study conducted in the $\mathrm{A} 3$ group, $\mathrm{AS}$ 
results obtained by the researcher with the micro RNA panel according to the stages of BC: Stage 0, A3A; Stage 1, A3B; Stage 2, A3C; Stage 3, A3D; Stage 4, A3E; NO, A3F and M0, is numbered as A3G.

In $\mathrm{BC}$ cases diagnosed with FNB method; $\mathrm{B} 2$ and $\mathrm{B} 3$, the AS results of the same researcher (Ohashi et al.), FNB (B2) and CNB (B3) in BC cases; in Kurita's study: FNB (B4), CNB (B5), combined FNB/CNB methods are shown with (B6) [26, 27].

The studies included in this study is summarized in Table 1 . The group in which $\mathrm{MM}$ analysis was performed in serum; named as group A (GpA), FNB and CNB applied group is named as group B (GpB) (Table 2). In this study, the recently published articles (2010-2020), in journals indexed in EMBASE and MEDLINE, reporting serum MMs and tissue FNB/CNB data, are included.

\section{Statistical analysis}

SPSS 23.0 package program was used for statistical analysis of the data. Categorical measurements were summarized as numbers and

Table 1: Data reported in literature for serum MMs and for invasive FNB and CNB methods in BC patients.

\begin{tabular}{lrrr}
\hline MMs in serum & No. of control & No. of & Ref. No. \\
& & BC & \\
\hline miR-195 & 44 & 83 & {$[15]$} \\
miR-21, miR-155, miR-365 & 99 & 21 & {$[16]$} \\
miR-1246, miR-1307-3p, miR-4634, & & & \\
miR-6861-5p, miR-6875-5p & 2,836 & 1,280 & {$[17]$} \\
His rich glycoprotein RNA & 60 & 30 & {$[18]$} \\
\hline FNB and/or CNB in tissues & & & \\
\hline FNB & - & 698 & {$[19]$} \\
FNB & - & 238 & {$[20]$} \\
CNB & - & 133 & {$[20]$} \\
FNB & - & 182 & {$[21]$} \\
CNB & - & 56 & {$[21]$} \\
Combined FNB and CNB & - & 43 & {$[21]$} \\
\hline
\end{tabular}

Table 2: Absolute sensitivities (\%), mis- (MD) and correct diagnosis (CD) (\%) in MM and FNB studies with BC patients.

\begin{tabular}{lrrrr}
\hline $\begin{array}{l}\text { Cancer } \\
\text { diagnosis }\end{array}$ & $\begin{array}{r}\text { MMs } \\
\text { GpA } \\
(\mathbf{n}=\mathbf{3 , 6 7 1 )}\end{array}$ & $\begin{array}{r}\text { FNB/CNB } \\
\text { GpB } \\
(\mathbf{n}=\mathbf{1 , 3 7 6})\end{array}$ & Total & p-Value \\
\hline $\mathrm{BC}(-)$ & $125(3.4)$ & $176(12.8)$ & $301(6.0)$ & $p<0.001$ \\
BC $(+)$ & $3,546(96.6)$ & $1,200(87.2)$ & $\begin{array}{r}4,746 \\
(94.0)\end{array}$ \\
Absolute & 90.6 & 80.7 & - & - \\
sensitivity & & & & \\
\hline
\end{tabular}

GpA, Group A cases; MMs, molecular markers; GpB, Group B cases; FNB, fine needle aspiration biopsy; CNB, core needle biopsy; BC (-), histopathologically positive but it is found as negative due to the limitation of the method. BC (+), both histopathologically and by the method it is found as positive. Values in parenthesis represent the percent of that group in the total number of patients in the same group. percentages. In comparison of categorical variables, Chi-square test and Fisher's Accuracy Test were applied. Statistical level was taken as 0.05 in all tests.

\section{Results}

In this study, the absolute sensitivity rates in GpA (the results reported for serum molecular markers) and $\mathrm{GpB}$ (the results reported for invasive FNB and CNB) were compared. It was observed that the success rate in the studies conducted in GpA (90.6\%) was statistically significantly higher than the studies in GpB $(80.7 \%)(\mathrm{p}<0.001)$ (Table 2). The percent absolute sensitivity rates (AS\%) vs. mis-diagnosis (MD\%) and correct diagnosis (CD\%) in GpA cases and $\mathrm{GpB}$ cases are shown in (Table 2) (Figure 1).

When the results of the reported studies with $\mathrm{MM}$ and FNB (CNB), were compared, it was observed that the most effective diagnostic methods, in decreasing order, are the A3D, A3B and A3F (N0), A3A, A3G (M0), B4 and B3 methods (Table 3). The percent ASs vs. diagnosed and misdiagnosed $\mathrm{BC}$ patients, at different stages of the disease determined using MM and FNB/CNB methods, is shown in Figure 2.

The most successful accurate ASs studies in GpA were carried out by Shihomura et al. [23], in their study, they performed five microRNA panel; A3D, A3B, A3F, A3A, A3G, (stages 3, stage 1, N0, stage 0 and MO cases). The average absolute sensitivity, specificity and accuracy obtained by using five miRNA panel in serum, at stages $0,1,2,3,4$, NO and M0, were 97.3, 98, 98.1, 95.6, 100, 96.2, 98.1 and 97.3\%, respectively (Figure 2) [23]. In the studies conducted with FNB and CNB methods $(\mathrm{GpB})$, the ASs were found in a decreasing order that B4 (93.3\%), B3 (91\%), B1 (89.7\%), B5

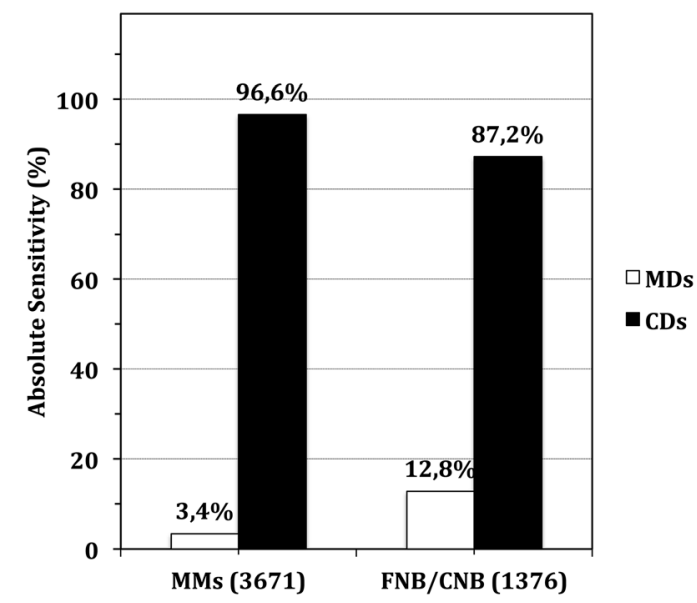

Figure 1: The percent AS vs. percent correctly diagnosed (\%CD) and percent mis-diagnosed (\%MD) BC patients plot, using MM and FNB (CNB) methods. 
Table 3: Absolute sensitivities (\%), mis- (MD) and correct diagnosis (CD) in MM and FNB studies with BC patients.

\begin{tabular}{lrrrrr}
\hline Author method Group & \multicolumn{3}{c}{ Cancer Diagnosis AS, \% } & Total Ref. No. \\
\cline { 2 - 5 } code \& Stage of BC & $\begin{array}{l}\text { Negative Positive } \\
\text { BC (-) }\end{array}$ & BC (+) & & & \\
\hline A1A; miR-195 & 12 & 71 & 85.5 & 83 & {$[15]$} \\
A2; miR-21, miR155, & 15 & 84 & 84.8 & 99 & {$[16]$} \\
miR365 & & & & & \\
A3A; stage 0 & 5 & 251 & 98.0 & 256 & {$[17]$} \\
A3B; stage 1 & 9 & 474 & 98.1 & 483 & {$[17]$} \\
A3C; five miRNA panel; & 17 & 375 & 95.6 & 392 & {$[17]$} \\
stage 2 & & & & & \\
A3D; five miRNA panel; & 0 & 22 & 100.0 & 22 & {$[17]$} \\
Stage 3 & & & & & \\
A3E; five miRNA panel; & 2 & 51 & 96.2 & 53 & {$[17]$} \\
Stage 4 & & & & & \\
A3F; five miRNA panel; N0 & 20 & 1,050 & 98.1 & 1,070 & {$[17]$} \\
A3G; five miRNA panel; M0 & 31 & 1,122 & 97.3 & 1,153 & {$[17]$} \\
A4; HRG protein & 8 & 52 & 86.6 & 60 & {$[18]$} \\
B1; FNB & 72 & 626 & 89.7 & 698 & {$[19]$} \\
B2; FNB & 59 & 179 & 75.2 & 238 & {$[20]$} \\
B3; CNB & 12 & 122 & 91.0 & 134 & {$[20]$} \\
B4; FNB & 13 & 182 & 93.3 & 195 & {$[21]$} \\
B5; CNB & 8 & 48 & 85.7 & 56 & {$[21]$} \\
B6; combined FNB + CNB & 12 & 43 & 78.2 & 55 & {$[21]$} \\
\hline
\end{tabular}

$\mathrm{GpA}$, serum molecular marker group; $\mathrm{GpB}$, fine needle biopsy group; FNB, fine needle aspiration biopsy; CNB, core needle biopsy; BC, breast cancer; $M D$, misdiagnosis; $B C(-)$, histopathologically positive but it is found as negative due to the limitation of the method; $B C(+)$, both histopathologically and by the method it is found as positive.

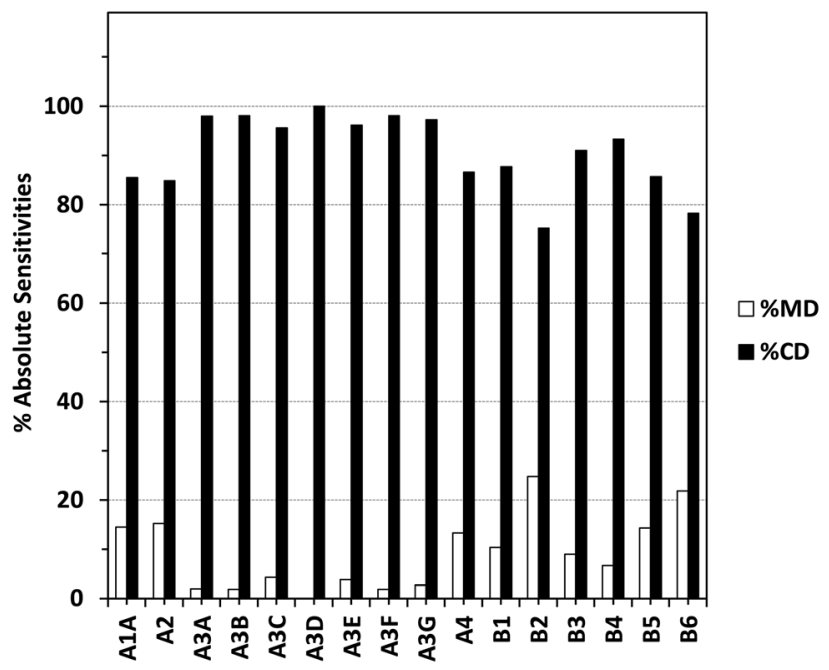

Figure 2: The percent AS vs. correctly diagnosed (\%CD) and misdiagnosed (\%MD) BC patients plot, at different stages of the disease were determined using MM and FNB (CNB) methods.
(85.7\%), B6 (78.2\%) and B2 (75.2\%) as given in Figure 2 and Table $3[26,27]$.

\section{Discussion}

MMs used in cancer diagnosis have several advantages. The two most important of these advantages are; 1 . Even in very small tumors, their expression increases in blood or/ and tissue. 2. Some of these markers are tumor-specific, thus providing tumor-specific information to the person. This information can be used not only in diagnosis, but also in prognosis and treatment.

Needle biopsies, especially in the last 10 years, are the most commonly used method for MMs studied in tissue samples. In addition, MM analyzes were performed in serum and in body fluids other than serum. The most important drawback of needle biopsies in BC is the implantation of tumor cells, few cases have been reported in the literature for $\mathrm{BC}[28,29]$.

In $\mathrm{BC}$ patients, molecular analysis of cancer cells enables us to be effective in treatment as well. In a study conducted by Tan et al. [30], they performed that miR-491 targets TPX2 gene and plays a tumor suppressor role in BC. In a comparative study conducted by Alfersi et al. [31], an increase in CDC20 miRNA expression in the ER positive subgroup of in $\mathrm{BC}$ patients has been shown, characterized by poor clinical outcome meaning poor response to endocrine therapy. In a study conducted by Cai et al. [32], transcriptional intermediary factor 1y (Tif1y) levels were measured in the serum of patients with $\mathrm{BC}$ to investigate the relationship between Tifly and overall survival (OS) and it was found that the Tifly positive patients have longer OS than the Tifly negative BC patients. Thus, the Tifly plasma levels are an independent prognostic factor and should be considered as a candidate to be an important prognostic MM in the BC [33].

The analysis of MMs in serum provides additional advantages. In a study by Oloomi et al. [33], the levels of some MMs (carcinoembryonic antigen, ER $\beta$, cytokeratin 19 and proto-oncogene) in tissue and serum in patients with $\mathrm{BC}$ were compared. Although, the difference between the tissue levels of these MMs, was not significantly different in healthy subjects and BC patients but their serum levels were significantly different [33]. Thus, this study indicates that some MMs detected in serum have superiority over tissue MMs in the diagnosis of $\mathrm{BC}$ [33].

The molecular analysis in cancer cells circulating in body fluids other than serum give promising results in the diagnosis of $\mathrm{BC}$. When making molecular analysis 
in body fluids, the major problem is the inability to ensure the homogeneity of the circulating cancer cells. Cheng and colleagues have developed the Hydro-Seq, a scalable hydrodynamic scRNA-seq barcoding technique, to obtain the homogeneity and catch cancer cells more easily, achieving successful results in their study on 21 patients [34].

In a study conducted by Wang et al. in $252 \mathrm{BC}, 82$ benign breast tumors, 127 healthy controls; preoperative and postoperative serum values of miR-21 were measured, expression levels were searched in patients with and without metastasis, and the effects of inhibition of miR-21 on $\mathrm{BC}$ metastasis and growth were investigated [35]. The result of their study indicates that serum levels of miR-21 were significantly higher in BC patients but decreased significantly after surgery [35]. On the other hand, higher expressions in patients with metastasis than patients without metastasis were observed and $\mathrm{BC}$ growth and metastasis decreased significantly with the inhibition of miR-21 expression [35].

According to the results obtained in this study, ASs obtained with serum MMs (GpA), appears to be significantly superior to the results obtained with the FNB and CNB (GpB) method in BC (Table 2; Figure 1). In addition, when the results in the published studies included in this study are evaluated separately, the methods using MM methods (diagnostic tests performed by Shimomura et al. in MO and NO BC cases with five microRNA panel: miR-1246, miR-1307-3p, miR-4634, miR-6861-5p, miR-6875$5 p$ ) in the ASs take the first 4 places (A3D, A3F, A3B, A3G) (Table 3) [23]. In the study conducted by Kazi, FNB results accompanied by ultrasonagraphy are in the 5 th place in the accurate diagnosis order in BC (Figure 2) [15].

According to the findings we obtained in this study, the highest ASs in GpA were obtained in the study performed by Shihomura with the tests performed with five micro RNA panel (miR-1246, miR-1307-3p, miR-6861-5p, miR-6875-5p) [23]. Then, the most successful ASs were obtained with the triple micro RNA panel (miR-21, miR-155, miR-365) in the study by Han et al. (Figure 2) [22]. When the absolute sensitivity rates in the studies conducted in $\mathrm{GpB}$ is analyzed, it is seen that the highest rate was obtained in the study conducted by Kurita et al. (Figure 2) [27]. When all the studies in GpA and GpB are taken into consideration, the fifth highest success rate in the ASs appears again in this group (Figure 2). However, one of the biggest disadvantages in cases where FNB is performed for the diagnosis of $\mathrm{BC}$ is that the ASs decrease as the cancer mass decreases [36].

However, the size of the cancer mass does not affect the ASs in studies with MMs [23]. According to the results of this study; even in M0 (A3G), NO (A3F), Stage 3 (A3D), Stage 0 (A3A) and Stage 1 (A3B) cases, the highest ASs were achieved with the five-point micro RNA diagnostic panel [23]. At the same time, these results show that MM diagnostic tests in serum are very suitable to use for BC screening. According to the results obtained, in this study, the diagnostic tests with micro RNAs in $\mathrm{BC}$ appear to be more effective than other tests.

One of the most commonly used noninvasive screening methods for BC diagnosis in the world is mammography. In a study by Warren et al. in England; a group of women (ages 50-70 years) who had mammography every year, the risk of $\mathrm{BC}$ due to mammography, although it changes according to radiation dose and factors affecting the dose, has been reported as 156/1 or 312/1 [37]. This risk will be completely eliminated when MMs in serum enter routine practice in $\mathrm{BC}$ screening.

It is more likely that MM diagnostic methods in $\mathrm{BC}$ are more cost-effective than the other diagnostic methods (such as FNB and CNB). The cost-effectiveness of FNB has been investigated by MM methods used in the diagnosis of thyroid cancers by Li et al. [38]. According to the results obtained in the study, MM methods were found to be more cost-effective [38]. The limited aspect of this study, while investigating the effects of molecular marker discoveries on the diagnosis and treatment methods in BC, the costeffectiveness could not analysed, due to the limited number of publication on this matter.

The study pointed out the general outcomes of the studies in the literature. Actually, the studies given in the present article investigated FNB and MM's sensitivities separately. Therefore, the conditions (staff, environment, patient) may differ from one study to another and thus, a concominant comparison study conducted in the same conditions may reveal more definitive outcomes. The authors of this study believe that, although there is not enough study with serum MMs in literature and this is the first study comparing serum MMs with the risky invasive FNB and CNB methods, in the near future, serum MMs will become an indispensible in the definitive diagnosis of $\mathrm{BC}$.

\section{Conclusion}

According to the results has been obtained, MMs measurement in serum is assumed as a noninvasive method that can be used safely in BC screening, definitive diagnosis and follow-up. Therefore, in the near future, serum MMs is likely to take a higher priority, in diagnostic approaches and screening programs for $\mathrm{BC}$. 
Research funding: None declared.

Author contributions: All authors have accepted responsibility for the entire content of this manuscript and approved its submission.

Competing interest: The authors have no conflicts of interest to declare.

\section{References}

1. He Z, Chen Z, Tan M, Elingarami S, Liu Y, Li T, et al. A review on methods for diagnosis of breast cancer cells and tissues. Cell Prolif 2020;53:1-16.

2. Uygun ZO, Yeniay L, Girgin Sağın F. CRISPR-dCas9 powered impedimetric biosensor for label-free detection of circulating tumor DNAs. Anal Chim Acta 2020;1121:35-41.

3. Banin Hirata BK, Oda JMM, Losi Guembarovski R, Ariza CB, Oliveira CECD, Watanabe MAE. Molecular markers for breast cancer: Prediction on tumor behavior. Dis Mark 2014;2014. https://doi.org/10.1155/2014/513158.

4. Amedee RG, Dhurandhar NR. Fine-needle aspiration biopsy. Laryngoscope 2001;111:1551-7.

5. Nakano S, Imawari Y, Mibu A, Otsuka MH, Oinuma T. Differentiating vacuum-assisted breast biopsy from core needle biopsy: is it necessary? Br J Radiol 2018;91:1-5.

6. Joulaee A, Kalantari M, Kadivar M, Joulaee S, Bahrani N, Mangual $M$, et al. Trucut biopsy of breast lesions: The first step toward international standards in developing countries. Eur J Canc 2012; 48s:648-54.

7. Radojicic J, Zaravinos A, Vrekoussis T, Kafousi M, Spandidos DA, Stathopoulos EN. MicroRNA expression analysis in triplenegative (ER, PR and HER2/neu) breast cancer. Cell Cycle 2011;10: 507-17.

8. Tang T, Guo C, Xia T, Zhang R, Zen K, Pan Y, et al. LncCCAT1 Promotes breast cancer stem cell function through activating WNT/ $\beta$-catenin signaling. Theranostics 2019;9:7384-402.

9. Stergiou N, Nagel J, Pektor S, Heimes AS, Jakel J, Brenner W, et al. Evaluation of a novel monoclonal antibody against tumorassociated MUC1 for diagnosis and prognosis of breast cancer. Int J Med Sci 2019;16:1188-98.

10. Menekse E, McKolanis J, Finn OJ, McAuliffe PF, Johnson R, Soran A. Anti-MUC1 antibody in nipple aspirate fluids correlates with tumor aggressiveness in breast cancer: a feasibility study. Dis Mark 2015. https://doi.org/10.1155/ 2015/179689.

11. Zhang YQ, Chen WL, Wei XL, Zeng D, Liang YK, Wu JD, et al. Overexpression of both VEGF-C and twist predicts poor prognosis in human breast cancer. Clin Transl Oncol 2019;21:1250-9.

12. Prihntono P, Usman AN, Binekada C, Hatta M, Islam AA. Patterns of dual-specific phosphatase 4 mRNA expression before and after neoadjuvant chemotherapy in breast cancer. Asian Pac J Cancer Prev 2019;20:1051-5.

13. Tsiakou A, Zagouri F, Zografos E, Samelis G, Gazouli M, Kalapanida D, et al. Prognostic significance of miR-34 rs4938723 T > C polymorphism in triple negative breast cancer patients. Clin Biochem 2019;68:9-14.
14. Shee K, Wells JD, Jiang A, Miller TW. Integrated pan-cancer gene expression and drug sensitivity analysis reveals SLFN11 mRNA as a solid tumor biomarker predictive of sensitivity to DNA-damaging themotherapy. PLoS One 2019;14:e0224267.

15. Elfgen C, Reeve K, Moskovszky L, Güth U, Radisic VB, Fleisch M, et al. Prognostic impact of PIK3CA protein expression in triple negative breast cancer and its subtypes. J Canc Res Clin Oncol 2019;145:2051-9.

16. Jiang L, Ren L, Zhang X, Chen H, Chen X, Lin C, et al. Overexpression of PIMREG promotes breast cancer aggressiveness via constitutive activation of NF- $\mathrm{KB}$ signaling. EBioMedicine 2019;43:188-200.

17. Tan GZ, Li M, Tan X, Shi ML, Mou K. MiR-491 Suppresses migration and invasion via directly targeting TPX2 in breast cancer. Eur Rev Med Pharmacol Sci 2019;23:9996-10004.

18. Majzoub RE, Kazan MF, Dine ANE, Makki R, Hamade E, Gree R, et al. A thiosemicarbazone derivative induces triple negative breast cancer cell apoptosis: possible role of miRNA-125a-5p and miRNA-181a-5p. Genes Genom 2019;41:1431-43.

19. Korobeynikov V, Borakove M, Feng Y, Wuest WM, Koval AB, Nikonova AS, et al. Combined inhibition of aurora $A$ and p21-activated kinase 1 as a new treatment strategy in breast cancer. Breast Canc Res Treat 2019;177:369-82.

20. Pour ZB, Nourbakhsh M, Mousavizadeh K, Madjd Z, Ghorbanhosseini SS, Abdolvahabi Z, et al. Up-regulation of miR-381 Inhibits NAD+ salvage pathway and promotes apoptosis in breast cancer cells. EXCLI J 2019;18:683-96.

21. Heneghan H, Miller N, Lowery A, Sweeney K, Newell J, Kerin M, et al. Circulating microRNAs as novel minimally invasive biomarkers for breast cancer. Ann Surg 2010;251:499-505.

22. Han JG, Jiang YD, Zhang CH, Yang YM, Pang D, Song YN. A novel panel of serum miR-21/miR-155/miR-365 as a potential diagnostic biomarker for breast cancer. Ann Surg Treat Res 2017; 92:55-66.

23. Shimomura A, Shiino S, Kawauchi J, Hiromi ST, Matsuzaki SJ, Ono $M$, et al. Novel combination of serum microRNA for detecting breast cancer in the early stage. Canc Sci 2016;107(3):326-334.

24. Marwa M, Sanaa E, Hebatallah S. Evaluation of histidine-rich glycoprotein tissue RNA and serum protein as novel markers for breast cancer. Med Oncol 2014;31:1-7.

25. Kazi M, Suhani P, Seenu M, Haresh KP. Fine-needle aspiration cytology (FNAC) in breast cancer: a reappraisal based on retrospective review of 698 cases. World J Surg 2017;41:1528-33.

26. Ohashi R, Matsubara M, Watarai Y, Yanagihara K, Yamashita K, Tsuchiya S, et al. Diagnostic value of fine needle aspiration and core needle biopsy in special types of breast cancer. Breast Canc 2016;23:675-83.

27. Kurita T, Tsuchiya S, Watarai Y, Yamamato Y, Harada 0 , Yanagihara $\mathrm{K}$, et al. Roles of fine-needle aspiration and core needle biopsy in the diagnosis of breast cancer. Breast Canc 2012;19:23-9.

28. Cho E, Kim MH, Cha SH, Cho SH, Oh SJ, Lee JD. Breast cancer cutaneous metastasis at core needle biopsy site. Ann Dermatol 2010;22:238-40.

29. Ishizuna K, Ota D, Okamoto J, Fukuuchi A, Tanaka R, Fujii A. A case of mucinous carcinoma of the breast in which needle tract seeding was diagnosed by preoperative diagnostic imaging. Breast Canc 2011;18:324-7. 
30. Xu X, Rajamanickam V, Shu S, Liu Z, Yan T, He J, et al. Indole2-carboxamide derivative LG25 inhibits triple-negative breast cancer growth by suppressing akt/mTOR/NF-KB signalling pathway. Drug Des Dev Ther 2019;13:3539-50.

31. Alfarsi LH, Ansari RE, Craze ML, Toss MS, Masisi B, Ellis IO, et al. CDC20 expression in oestrogen receptor positive breast cancer predicts poor prognosis and lack of response to endocrine therapy. Breast Canc Res Treat 2019;178:535-44.

32. Cai F, Cai L, Zhou Z, Pan X, Wang M, Luis MA, et al. Prognostic role of Tif1y expression and circulating tumor cells in patients with breast cancer. Mol Med Rep 2019;19:3685-95.

33. Oloomi M, Moazzezy N, Bouzari S. Comparing blood versus tissue-based biomarkers expression in breast cancer patients. Heliyon 2020;6:e037282.

34. Cheng YH, Chen YC, Lin E, Brien R, Jung S, Chen YT, et al. Hydroseq enables contamination-free high-throughput single-cell RNA- sequencing for circulating tumor cells. Nat Commun 2019;15: 1-11.

35. Wang H, Tan Z, Hu H, Liu H, Wu T, Zheng C, et al. MicroRNA-21 promotes breast cancer proliferation and metastasis by targeting LZTFL1. BMC Canc 2019;19:738.

36. Manfrin E, Falsirollo F, Remo A, Reghellin D, Mariotto R, Dalfior D, et al. Cancer size, histotype, and cellular grade may limit the success of fine-needle aspiration cytology for screen-detected breast carcinoma. Cancer 2009;117:491-9.

37. Waren LM, Dance DR, Young KC. Radiation risk of breast screening in England with digital mammography. Br J Radiol 2016;89:20150897.

38. Li H, Robinson KA, Anton B, Saldanha IJ, Ladenson PW. Costeffectiveness of a novel molecular test for cytologically indeterminate thyroid nodules. J Clin Endocrinol Metabol 2011; 96:1719-26. 